\section{Voir Dire}

Nathalie DeFabrique

Cook County Department of Corrections,

Chicago, IL, USA

\section{Synonyms}

Qualifying an expert; Selection of jurors

\section{Definition}

The term "voir dire" is a phrase derived from the French meaning to "speak the truth." It refers to the process by which possible jurors are questioned about their backgrounds and potential biases before being chosen to sit on a jury. When individuals are called to jury duty, they gather at the courthouse to form a pool of potential jurors. From there they are called in groups for specific criminal or civil trials. In these groups, they may be questioned by the judge and the attorneys for each side about their background, life experiences, and opinions. The questioning aims to determine the individual's ability to weigh the evidence justly and without bias. Each attorney attempts to select jurors who are most sympathetic to their side.

\section{Cross-References}

- Cross-Examination

- Expert Witness

\section{References and Readings}

Brodsky, S. L., \& Poythress, N. G. (1985). Expertise on the witness stand: A practitioner's guide. In C. P. Ewing (Ed.), Psychology, psychiatry and the law: A clinical and forensic handbook.

Cleary, G. P. (2007). Trial evidence foundations. James.

Kovera, M. B., Cidkinson, J. J., \& Cutler, B. L. (2003). Voir dire and jury selection. In A. Goldstein (Ed.), Handbook of psychology (Vol. 11). Forensic psychology. Hoboken: Wiley. 